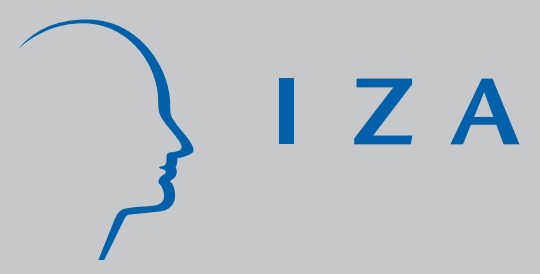

IZADP No. 3551

The Economic Returns to a Second Official Language:

English in Quebec and French in the Rest-of-Canada

Louis N. Christofides

Robert Swidinsky

J une 2008 


\title{
The Economic Returns to a Second Official Language: English in Quebec and French in the Rest-of-Canada
}

\author{
Louis N. Christofides \\ University of Cyprus, University of Guelph \\ and IZA \\ Robert Swidinsky \\ University of Guelph
}

Discussion Paper No. 3551

June 2008

IZA

P.O. Box 7240

53072 Bonn

Germany

Phone: +49-228-3894-0

Fax: +49-228-3894-180

E-mail: iza@iza.org

\begin{abstract}
Any opinions expressed here are those of the author(s) and not those of IZA. Research published in this series may include views on policy, but the institute itself takes no institutional policy positions.

The Institute for the Study of Labor (IZA) in Bonn is a local and virtual international research center and a place of communication between science, politics and business. IZA is an independent nonprofit organization supported by Deutsche Post World Net. The center is associated with the University of Bonn and offers a stimulating research environment through its international network, workshops and conferences, data service, project support, research visits and doctoral program. IZA engages in (i) original and internationally competitive research in all fields of labor economics, (ii) development of policy concepts, and (iii) dissemination of research results and concepts to the interested public.
\end{abstract}

IZA Discussion Papers often represent preliminary work and are circulated to encourage discussion. Citation of such a paper should account for its provisional character. A revised version may be available directly from the author. 


\section{ABSTRACT \\ The Economic Returns to a Second Official Language: English in Quebec and French in the Rest-of-Canada*}

Canada is a country with two official languages, French and English. The need for both languages in Quebec and the Rest-of-Canada (ROC) generates a demand for bilingualism and investment in the acquisition of a second official language. Knowledge of an additional language may be associated with enhanced earnings because it may reflect what might generically be called 'ability' bias or because it may actually be useful at the workplace. Until now, available data did not indicate whether bilingualism was actually being used at work. However, the 2001 Census reports, for the first time, whether an individual is bilingual and the extent to which this skill is actually used at work. Conditioning on both knowledge and use allows us to measure the additional earnings which accrue to the use of a second language more cleanly. We find very substantial, statistically significant, rewards to second official language use in Quebec and much smaller, not statistically significant, effects in the ROC.

JEL Classification: J01, J24, J31

Keywords: $\quad$ wages, language knowledge, language use

Corresponding author:

Louis N. Christofides

Department of Economics

University of Cyprus

Kallipoleos 75

P.O. Box 20537

1678 Nicosia

Cyprus

E-mail: louis.christofides@ucy.ac.cy

\footnotetext{
* The authors are members of the Canadian Language and Literacy Research Network. This research was supported by the CLLRNet and the SSHRC.
} 


\section{INTRODUCTION}

There are many reasons why a person, fluent in only one language, may choose to learn a second language. There are cultural reasons, such as the desire to experience first hand the traditions, customs, mannerisms, social and religious structures that characterize other societies. There are intellectual reasons, such as the desire to read classics in the original language, to have direct access to scientific and technical papers, to hone first-language literacy, to improve general cognition, or, simply, to satisfy intellectual curiosity. There are reasons associated with personal identity, such as re-visiting a lost heritage language. There are political reasons, the desire to participate in the political life of a bilingual nation, or to promote national unity in a country divided by language. And there are economic reasons, primarily the desire to obtain an advantage in a labour market in which knowledge of languages is a valuable asset.

In this study we focus on the economic incentives for learning a second official language. Given that Canada is a linguistic duality, with French dominant in Quebec and English dominant in the ROC, we estimate and compare the labour market returns obtained by Francophones in Quebec and Anglophones in the ROC who learn a second official language. ${ }^{1}$ While educators, especially those promoting French immersion programs in the ROC, tend to emphasize the cultural, linguistic and cognitive merits of learning French as a second language (Lambert, 1977; Turnbull, Lapkin and Hart, 2001; Edwards, 2003), parents, students and employers are more likely to focus on the economic value of any particular set of language skills. For example, the organization of Canadian parents advocating French second-language (FSL) education cites 'practical career benefits' and 'bilingual career development' among the reasons why parents

\footnotetext{
${ }^{1}$ We focus on only these two groups because Anglophones in Quebec and Francophones in the ROC are almost universally bilingual. In the data sample used in this study (see Section II, below), 98.3 percent of all Francophone men and 97.5 percent of Francophone women working in the ROC were bilingual. The corresponding proportions for
} 
should consider French immersion educational programs for their children (CPF, 2004; p.2).

Students also tend to emphasize the labour market benefits of FSL education. Several independent surveys reveal that a high proportion of French immersion graduates consider enhanced job opportunities and career prospects as the most significant long-term effects of learning French as a second language (Hussum and Bryce, 1991; MacFarlane and Wesche, 1995; Savoie, 1997). As well, there is evidence that employers, in general, are cognizant of the economic value of bilingual language skills; Chorney (1998), drawing on special surveys, reports that employers, especially in leading exporting and innovative firms, include French/English bilingual skills among the many attributes they look for in prospective employees.

Bilingual language skills may have an effect on a variety of labour market outcomes; they may, for example, generate higher labour force participation, lower unemployment, increased job mobility, wider choices of jobs, more job training, more rapid promotion, and higher labour market earnings. We emphasize the effect of bilingual language skills on the labour market earnings of Canadian paid workers who learn French or English as a second language. Admittedly, earnings are but one dimension of labour market outcomes that language skills may affect (Savoie, 1997). However, not only are earnings one of the most critical labour market outcomes, but promotion, job training, job mobility, occupational and job choice are all ultimately reflected in labour market earnings.

There now exist a number of studies that yield estimates of labour market returns to bilingual language skills in Canada; see, for example, Grenier (1987), Shapiro and Stelcner (1987, 1997), Chiswick and Miller (1988), Vaillancourt (1992, 1997), Christofides and Swidinsky (1998), and Albouy (2006). These studies use various methodologies, data sets, time periods, 
regions and linguistic groups, making direct comparisons somewhat difficult. In general, the evidence shows that bilingual Francophone men in Quebec earn substantially more than their unilingual counterparts; estimates, based on the 1991 Census, indicate a bilingual earnings differential ranging from 7 to 16 percent. The lower estimate, reported in Vaillancourt (1997), is based on a sample of full and part-time workers and a wage equation that does not control for industry and occupation. Shapiro and Stelcner (1997) report a bilingual earnings premium of 9.1 percent, derived from a sample of full time/full year paid workers (Canadian-born and immigrants), using an OLS log earnings equation which excludes employment characteristics. The estimated bilingual premium falls to 7.5 percent when industry and occupation variables are included. By comparison, Christofides and Swidinsky (1998) report a 10.5 percent premium; this is derived from a sample that includes both full- and part-time Canadian-born paid workers and self-employed individuals, and an OLS log earnings equation that controls for industry and occupation. Finally, the most recent estimate presented in Albouy (2006), suggests that the 1990 hourly earnings bilingual gap for Quebec Francophone men was roughly 16 percent (his Figure A2). Moreover, Albouy (2006) estimates that the bilingual gap fell by about 6 points between 1970 and 2000, possibly due to a fall in the relative demand for English in the Quebec labour market.

Estimates of bilingual premiums for Francophone women in Quebec are far less consistent. Vaillancourt (1997) finds a net effect of 11.24 percent, while Shapiro and Stelcner (1997) find a 10.7 percent bilingual earnings differential when employment characteristics are excluded and a 7.5 percent differential when they are included. However, Christofides and Swidinsky (1998) fail to detect any bilingual premium for Francophone women in Quebec. 
Considerably less information is available concerning the economic returns to bilingual language skills in the ROC. Chiswick and Miller (1988), relying on data from the 1981 Census, find that the 1981 earnings of bilingual Anglophone men were 3.9 percent higher than the earnings of unilingual men. This finding is based on a sample of Canadian-born men, aged 25-64, who worked one or more weeks as paid workers or were self-employed. Christofides and Swidinsky (1998) report very similar findings; they estimate a bilingual earnings differential of 3.0 percent in 1981 and 2.2 percent in 1991. However, Albouy (2006) finds a significantly higher Anglophone bilingual gap for men; estimates for the period 1970 to 2000 range from 12 to 15 percent (Figure A2). Such implausibly high differentials, he admits, may be due to differences in unobservable characteristics rather than returns to language capital (p. 26). Estimates of the bilingual earnings differential for Anglophone women in the ROC are even more scarce; Christofides and Swidinsky (1998) find a differential that is marginally higher than that for men, and unchanged over the 1981-91 census periods, i.e. 4.5 percent in 1981 and 4.4 percent in 1991.

These studies share some data-related attributes. First, they do not control for the quality of English or French second language skills; the information available is typically binary and based on self-reporting. As Savoie (1997) points out, such information may contain significant measurement error; if present, this error will bias downward the estimator of the coefficient on language proficiency. Second, estimators of the additional earnings accruing to bilingualism may suffer from the ability bias that plagues estimators of the additional earnings ('returns' for short) associated with education generally. Third, the additional earnings from a language should be based not on knowledge of the language but on its use in the marketplace - language knowledge is a necessary, but not a sufficient, condition for language use (Vaillancourt, 1992). This third issue, which is the focus of the present paper, is not unrelated to the problems of quality and ability 
outlined above. Fourth, most studies ignore the possibility that language skills may be endogenous to the earnings equation. Grenier (1987), Shapiro and Stelcner (1997) and

Christofides and Swidinsky (1998) all deal with the issue of language endogeneity, but only the latter study addresses the decision to acquire bilingual (English/French) language skills or remain unilingual in French or English. ${ }^{2}$ In principle, sample selection may be an acute problem when one considers the effects of bilingual language skills on earnings, particularly for Anglophones in the ROC. French immersion schooling is an increasingly important avenue for acquiring French language competency; 6.98 percent of all children in elementary, intermediate, and secondary schools were enrolled in French immersion programs in 2002-03 (CPF, 2004). Not only are children entering French immersion selected into the program on the basis of program compatibility, but they generally come from better-educated, higher-income, urban families (Allen, 2004). Since family characteristics may have a bearing on subsequent earnings (Murmane, Willett and Levy, 1995; Currie and Thomas, 2001), these characteristics should be allowed to influence the decision to acquire language skills. However, attempts to deal with sample selection, using mother tongue and other controls as identifying forces, did not lead to results that were significantly different from those actually reported in the current paper and we do not pursue this matter further. ${ }^{3}$

\footnotetext{
${ }^{2}$ Grenier (1987) explains the earnings of individuals who stayed in Quebec between 1976 and 1981 and those who moved; language skills enter into the Probit equation explaining the migration decision. Shapiro and Stelcner (1997) use selection to address the issue of inclusion in the wage sample.

${ }^{3}$ Consistent with this finding, in Christofides and Swidinsky (1998, p. 151), the selection-adjustment variables were significant in a very small fraction of the estimated equations only and the correction for possible endogeneity produced but minor changes to the estimated wage equations. Shapiro and Stelcner $(1997$, p. 121), in their own particular context, likewise find that the effect of selection is minimal. Albouy (2006) refrains from correcting for endogeneity, arguing that 'Credible identification is difficult as it relies on finding variables which affect the decision to be bilingual but are uncorrelated to any unobservable determinants of earnings.'(fn.41).
} 
In this paper we provide separate estimates of the additional earnings resulting from the knowledge and use of bilingual language skills, based on data for individuals from the 2001 Census. This data set differs from information used in earlier studies in that individuals in the 2001 Census are identified not only by their official language knowledge status but also by the languages used at work. The additional information allows us to compare (i) the earnings of individuals who are unilingual and use only their mother tongue at work, (ii) the earnings of bilingual individuals who use only their mother tongue at work, and (iii) the earnings of bilingual individuals who actually use both official languages at work. Barring differences in the quality of French or English second language skills, or language-related differences in ability, the differential (ii)-(i) should measure the return to second-language knowledge whereas the differential (iii)-(ii) should measure the return to second-language use given its knowledge. We stress that, due to data availability, the differential (iii)-(ii) has never been calculated.

The assumptions in the last but one sentence may, of course, be too strong. For example, bilinguals, on average, may possess greater ability than unilinguals so that the difference (ii)-(i) may incorporate what we have generically called ability bias, and bilinguals who use both official languages at work may possess better second-language skills than bilinguals who use only their mother tongue so that the differential (iii)-(ii) may incorporate the effect of superior language fluency. By controlling for language knowledge when measuring the additional return associated with language use, this latter return, if at all tainted by ability bias, will be tainted only to the extent that bilingual users of a second language are more able/fluent than bilingual non-users of the second language. We use the results for bilingual users of the second language in the ROC to adjust the Quebec returns for this possibility. This adjusted return to language use in Quebec may, 
under circumstances discussed below, be reasonably pure and offers a new perspective in the debate on the value of bilingualism.

The following section contains a description of the data and a discussion of the specification of the econometric approach employed in this study. The results and analysis are presented in Section III. The final section contains a brief summary of the critical findings and some concluding observations.

\section{DATA AND MODEL}

Data for this study are obtained from the individual file of the 2001 Census Public Use Microdata File. To construct the working sample for the ROC we retain observations only if the individual is 15-64 years of age, is Canadian-born, has an English mother tongue, claims official language fluency in English only or in both English and French, has at least a high school certificate, and is a paid worker who worked full-time, full-year (FTFY) in 2000. These restrictions are imposed to make individuals in the working sample more homogeneous. The same restrictions are imposed on the working sample for Quebec; the one exception is that only individuals whose mother tongue is French and whose official language is French, or both English and French, are retained in the sample.

Several additional data refinements are required to define language at work. For individuals in the ROC who declare official language fluency in English only we exclude all observations in which the language used most often or frequently at work is other than English. The number of observations lost is fairly small, mostly individuals who frequently use a nonofficial language at work. The analogous restriction is imposed on individuals in Quebec who declare French as their only official language. For individuals in both the ROC and Quebec who declare fluency in both English and French we exclude all observations in which the language 
most often used is other than English, or French, or English and French. For the English language group we retain observations only if the language frequently used is either none other (English) or French; for the French language group we retain observations only if the language frequently used is either none other (French) or English. For the bilingual group, that is the group in which individuals most often use both English and French, we retain observations only if the language frequently used is also English/French. In the ROC sample, the above exclusions result in losses of 327 and 361 observations for men and women, respectively; in the Quebec sample the respective losses are 661 and 677 observations.

The above data refinements allow us to classify all individuals in the working sample into six potential work-language groups, based on official language and language at work. In the ROC, individuals whose official language is English only are assigned to a single unilingual category, UNIL/ENGLISH. Individuals who are bilingual are assigned to the following five work-language categories: Mostly English, frequently English (BIL/MEFE), mostly English, frequently French (BIL/MEFF), mostly French, frequently English (BIL/MFFE), mostly French, frequently French (BIL/MFFF) and mostly bilingual, frequently bilingual (BIL/MBFB). However, the latter three groups contain very few observations; consequently they are combined into a single category, BIL/FRENCH. The respective categories in Quebec are unilingual French (UNIL/FRENCH), bilingual only French (BIL/MFFF), bilingual mostly French frequently English (BIL/MFFE), and bilingual English (BIL/ENGLISH); this latter group is comprised of individuals who work primarily in English (BIL/MEFF), only in English (BIL/MEFE), or both English and French (BIL/MBFB).

Select summary statistics, presented in Table 1, show that 6.7 percent of the 44,557 men in the ROC working sample are bilingual; the unadjusted mean annual earnings of bilingual men are 
14.7 percent higher than the earnings of unilingual men. Among Anglophone men who are bilingual, 71.8 percent use only English at work. The vast majority of those who use French at work (24.7 percent) work mainly in English, but frequently resort to French; French is the main work language for only a very small minority ( 3.5 percent). Table 1 also shows that using French at work is not a pre-condition for earning a bilingual premium; bilingual men who use only English (BIL/MEFE) earn 15.2 percent more than unilingual Anglophone men. Those who use French frequently (BIL/MEFF) receive a slightly higher premium (16.6 percent). However, Anglophone men whose work language is primarily French (BIL/FRENCH) earn considerably less (9.1 percent) than unilingual men. We note that this last group contains relatively few observations (103 individuals) and may be dominated by special cases.

The summary statistics for Anglophone women in the ROC are very similar to the mean values for men, except that a slightly higher proportion ( 8.7 percent) are bilingual and, of these, a slightly higher proportion, 31.3 percent, use French at work (24.3 percent frequently and 7.0 percent mostly). The unadjusted bilingual-unilingual earnings differential is also higher, by almost 4 percent. The earnings differential for bilingual women who use only English at work is 18.3 percent; the differential for those who use French frequently is 23.0 percent. In contrast to bilingual men, women whose work language is primarily French earn 4.1 percent more than women who do not have French second language skills but, again, this is a small group of individuals (206).

In Quebec, English second language (ESL) proficiency is much more prevalent than FSL proficiency in the ROC. Of the 15,836 Francophone men in the Quebec sample, 59.2 percent are bilingual, that is, learned English as their second language, and the majority of bilinguals tend to use their English language skills at work, 43.6 percent frequently and 15.5 percent mostly. On 
average, Francophone men who have ESL skills earn 27.9 percent more than men who are proficient in only the French language. However, the unadjusted earnings advantage of bilingual men whose work language is exclusively French is only 16.4 percent. Men who use English frequently at work earn 35.6 percent more, while those who rely mostly or exclusively on English earn 37.1 percent more; note that this latter group is very much larger than the analogous group of men in the ROC.

A smaller proportion of Francophone women than men tends to be proficient in English, and those who do acquire ESL skills tend, on average, to enjoy a smaller bilingual earnings advantage. Only 52.5 percent of the 12,448 French-language women in the Quebec sample are bilingual; on average, they earn 21.9 percent more than women who are not bilingual. Bilingual women who work exclusively in French earn a 21.5 percent premium; this is almost indistinguishable from the bilingual premium (22.0 percent) earned by women who frequently use English at work, or the bilingual premium (22.9 percent) earned by women who work mostly or only in English; this latter group of Quebec women is very much larger than the comparable group of women in the ROC.

Estimates of the adjusted effects of FSL and ESL skills on labour market earnings in the ROC and Quebec, respectively, are derived from a standard OLS log-earnings equation of the form:

$$
\ln E=\alpha+\beta X+\gamma Z+\varepsilon
$$

where $\ln E$ is the natural logarithm of annual earnings, $\mathrm{X}$ is a set of variables that identify language at work, $\mathrm{Z}$ is a set of control variables, $\alpha, \beta$ and $\gamma$ are the intercept and constant coefficients to be estimated, and $\varepsilon$ is an error term assumed to have classical properties. In the ROC equation, language at work variables include BIL/MEFE, BIL/MEFF, and BIL/FRENCH, 
with UNIL/ENGLISH as the reference group; in the Quebec wage equation, the language at work variables include BIL/MFFF, BIL/MFFE, and BIL/ENGLISH, with UNIL/FRENCH as the reference group. Both earnings equations control for work experience, urban-rural location, marital status and schooling; the ROC equation has, in addition, a set of regional variables (see Appendix for variable definitions). Similar explanatory variables are fairly standard in earnings equations that employ census data (see, for example, Shapiro and Stelcner, 1987; Chiswick and Miller, 1988).

Occupation and industrial sector, two variables that appear frequently in earnings functions, are contentious. The effect of bilingual language skills may be embodied not only in wage structures within occupation and industry but in choices of occupation and industrial sector as well. Accordingly, we present results from model specifications which alternatively exclude and include industry and occupation; these alternative results enable us to differentiate between the intra and inter-industry earnings effects of second language skills.

\section{ECONOMETRIC RESULTS AND DISCUSSION}

The regression results for the ROC are presented in Table 2. We focus initially on Equation (1), the estimated $\ln$ earnings equation for men in which controls for industry and occupation are excluded. The estimated coefficients on the control variables have the expected signs, and almost all are significantly different from zero at the 1 percent level. Earnings in Ontario are higher than in other regions in the ROC except the West. Labour market experience has a positive, but nonlinear, effect on earnings, males living in major urban centers have significantly higher earnings, as do males who are married or divorced. The estimates also show that the returns to schooling increase as men progress from high school certification to completion of post-graduate degrees. 
The estimated work-language coefficients show that both language knowledge and language at work have an effect on earnings. Compared with men who are fluent only in English, the earnings of men who are bilingual but work exclusively in English are 3.8 percent higher, the earnings of bilingual men who frequently use French at work are 5.4 percent higher, but the earnings of the very small number of bilingual men who work equally, mostly or exclusively in French are 8.4 percent lower. However, only the BIL/MEFE and BIL/MEFF coefficients are significantly different from zero at the 5 percent level. These results suggest that men who acquire French as a second language, but are otherwise indistinguishable from those who are fluent in only English, earn significantly higher wages. However, this premium may incorporate the interplay between language acquisition and certain unobserved characteristics, such as assertiveness and ability, or family characteristics, which are also known to yield a labour market advantage; unfortunately, there is no easy method to distinguish between these two alternative interpretations. The net effect of actually using French in the workplace is given by the difference between the estimated BIL/MEFF and BIL/MEFE coefficients; this effect is equal to 1.6 percent. However, a test of the statistical significance of this differential indicates that the actual use of French at work does not contribute additionally and significantly to the earnings of those who have French second-language skills. ${ }^{4}$ The implication of this result is that the use of French as a

\footnotetext{
${ }^{4}$ To test whether the net earnings effects of actually using French at work are statistically significant we re-estimate equation (1), using the fully equivalent specification for the three language-at-work variables $\operatorname{lnE}=\alpha+\beta 1$ Bilingual $+\beta 2 \mathrm{BIL} / \mathrm{WORK}+\beta 3 \mathrm{BIL} / \mathrm{FRENCH}+\gamma \mathrm{Y}+\varepsilon$ where BILINGUAL is defined as (BIL/MEFE + BIL/MEFF + BIL/FRENCH) and BIL/WORK as (BIL/MEFF + $\mathrm{BIL} / \mathrm{FRENCH}$ ). The set of control variables, $\mathrm{Z}$, remains unchanged. The estimated coefficient $\beta 1$ captures the earnings effect of being bilingual, $\beta 2$ the added effect of using French in the workplace, and $\beta 3$ the added effect of using French mostly or exclusively. The partial results obtained from this regression are given below. All remaining coefficients remain unchanged from those reported in equation (1), Table 2.
}

BILINGUAL .038 (2.48)

BIL/WORK .016 (0.55)

BIL/FRENCH -.137 (1.93)

The BIL/WORK coefficient shows that the 1.6 percent additional earnings effect of using French at work is not significantly different from zero at the 5 percent level. The estimated BIL/FRENCH coefficient shows that working 
second official language may have no discernible additional productivity effect on the labour market earnings of bilingual men in the ROC. We comment on this and our further results below.

In Equation (2) the list of control variables is augmented by seven occupational and six industrial sector variables. These additional variables change the coefficients and corresponding tscores of the estimated control variables only marginally. However, not only do the estimated coefficients on the language variables fall sharply, but they all become not significantly different from zero at the 5 percent level. It thus appears that language has an effect not so much on wages within industry and occupation as on the choice of industry and occupation. Indeed, men who have French second-language skills tend to be disproportionately employed in the higher-paying occupations and industrial sectors. As the Appendix Table 1A shows, 22.7 percent of all men in the BIL/MEFE work-language group, 29.3 percent in the BIL/MEFF group, and 16.5 percent in the BIL/FRENCH group are employed as managers; an additional 34.7, 30.6 and 42.6 percent, respectively, are employed as professionals. Annual earnings in these two occupations are well above the overall mean of $\$ 52,737$ (not shown in Table 1A). By contrast, only 17.1 percent of all men in the UNIL/ENGLISH group are employed as managers and 21.2 percent are employed as professionals. As well, bilingual men tend to be over-represented in the public and semi-public sectors. Bilingual men in the BIL/MEFF group are especially over-represented in the public sector (33.2 percent compared with 8.8 percent for the UNIL/ENGLISH group), while those in the BIL/FRENCH group are vastly over-represented in the semi-public sector (31.1 percent compared with 8.6 percent in the UNIL/ENGLISH group). However, the impact of this

mostly or exclusively in French lowers the earnings of bilingual men using French by 13.7 percent; however, this effect, which is based on a very small number of observations, is not significantly different from zero at the 5 percent level. It should be noted that the sum of $\beta 1$ and $\beta 2$ is .054 , while the sum of $\beta 1, \beta 2$, and $\beta 3$ is -.084 . Allowing for rounding, these are the coefficients for BIL/MEFF and BIL/FRENCH, respectively, reported in equation (1), Table 2. Note that, because of the small size of the coefficients involved, we refer to them as percentage effects. 
unbalanced sectoral employment pattern is somewhat mitigated by the small earnings differentials that prevail between the public, semi-public and private sectors.

Language appears to have a stronger influence on the earnings of women in the ROC. Equation (3), Table 2, which captures both the inter- and intra-industry and occupation effects, shows that women who are fluent in French but use only English at work earn 6.6 percent more than women who are fluent only in English. Those who additionally use French frequently at work earn 9.3 percent more, but those for whom French is the primary work language earn 7.3 percent less. However, the latter coefficient is based on a very small number of observations and is not significantly different from zero at the 5 percent level. The difference between the estimated $\mathrm{BIL} / \mathrm{MEFF}$ and BIL/MEFE coefficients, which indicates the net earnings value of using French at work, is 2.7 percent. However, a test of significance, using the methodology described in footnote 4 above, shows that the increased earnings associated with the frequent use of French at work is not statistically significantly different from zero at the 5 percent level. ${ }^{5}$ On the other hand, extensive use of French at work is associated with a significant reduction in the annual earnings of bilingual women; the estimated BIL/FRENCH coefficient is -16.7 percent, with an absolute $\mathrm{t}-$ value of 3.19. Overall, a bilingual woman who uses French extensively at work would earn 7.3 percent less $(6.6+2.7-16.7)$ than a unilingual woman but, as shown in Table 2 , this effect is not significantly different from zero. These results show that the economic rewards (if any) to women in the ROC who invest in French second-language training are not embedded in language use if one controls for knowledge of this second language.

\footnotetext{
${ }^{5}$ The estimated coefficients and t-values for the language variables derived from the re-estimated earnings equation are as follows:

BILINGUAL .066 (4.28)

BIL/WORK .027 (0.96)

BIL/FRENCH -.167 (3.19)
} 
Equation (4), which includes controls for sector and occupation, shows substantial earnings effects for women within specific industries and occupations. Adding controls for sector and occupation reduces the BIL/MEFE coefficient to .046, and the BIL/MEFF coefficient to .065, but both remain significantly different from zero at the 5 percent level. This result suggests that bilingual women who use French sparingly, or not at all, have access to better-paying jobs, and, as the occupational and sectoral distribution of employment presented in Table 1A shows, they maximize their labour market advantage by also gravitating to managerial/professional occupations and the public sector. On the other hand, the choices of sector and occupation appear not to be significant determinants of the earnings of bilingual women who work in jobs where the work-language is predominantly French; the estimated BIL/FRENCH coefficient remains essentially unchanged and statistically not significantly different from zero. One plausible explanation of this last result is the sectoral concentration of the women in this work-language group. Data not shown in Table 1A indicate that nearly half (49.0 percent) are employed in the (semi-public) education sector, almost exclusively as teachers. By comparison, only 11.4 percent of women in the UNIL/ENGLISH group, 17.3 percent in the BIL/MEFE group and 21.3 percent in the BIL/MEFF group are employed in this sector. In the latter three work-language groups, women employed in education also tend to have higher annual earnings than women in the BIL/FRENCH group. Commitment to a profession may be one reason why bilingual women in the ROC accept jobs that require the exclusive use of French in the face of viable, higher-paying, alternatives.

The regression results for paid workers in Quebec whose mother tongue is French are presented in Table 3. The control variables perform as expected in all four regressions; almost all the estimated coefficients are significantly different from zero at the 5 percent level. The 
estimated coefficients on the work-language variables in Equation (1) show that language capital has a strong, positive, effect on the earnings of Francophone men. The earnings of men who acquire English as a second language but work exclusively in French are 7.0 percent higher than the earnings of men in the unilingual French control group. However, the earnings of bilingual men who use English frequently at work are 20.9 percent higher and the earnings of those who use English exclusively or predominantly are 18.2 percent higher than those of unilinguals. The net earnings differential associated with using English frequently at work is 13.9 percent; using English exclusively or extensively increases net earnings by 11.2 percent. In contrast to the results in the ROC earnings estimates (see fn. 4), the BIL/WORK coefficient is significantly different from zero at the 1 percent level, indicating that using English at work has an additional significant positive effect on earnings. ${ }^{6}$ However, there is no significant further impact on earnings when English is used mostly or exclusively in the workplace - BIL/ENGLISH has a coefficient which is not significantly different from zero.

The estimated effects of language on the earnings of Francophone men in Quebec remain statistically significant even when industry and occupation are added to the list of controls. Equation (2) shows that the estimated BIL/MFFF, BIL/MFFE, and BIL/ENGLISH worklanguage coefficients fall by less than a third (to $4.8,15.7$ and 12.7 percent, respectively); all three coefficients remain significantly different from zero at the 1 percent level. The coefficient on BIL/WORK also retains significance. This result is not unexpected, given that the distribution of employment among industrial sectors and occupations is fairly consistent among the four work-

\footnotetext{
${ }^{6}$ The language coefficients and t-values derived from the re-estimated earnings equation are as follows: BILINGUAL .070 (4.64) BIL/WORK .140(8.66) BIL/ENGLISH -.027 (1.24)
} 
language groups (see Table 2A). While bilingual Francophone men are over-represented in the public sector and, especially, the manager/professional occupations, they are, generally, underrepresented in the semi-public sector; however, the unilingual-bilingual imbalance is not as striking as it is among Anglophone men in the ROC.

How much of the estimated returns can be attributed to language capital? We have considered the possibility that the additional earnings associated with language knowledge may be more due to unobservable characteristics than language capital. It is possible that the additional earnings associated with language $u s e$ are also due primarily to unobservable characteristics. The bilingual Francophones who obtain jobs that require knowledge of English may be those who have superior ability and/or second-language skills. Thus our estimated BIL/MFFE and BIL/ENGLISH coefficients may overstate the returns associated with the actual use of a second language at work. There is some indirect evidence that bilingual Francophones who use English at work generally possess superior English-language skills. Bilingual Francophones for whom English or English and French are home languages tend to be employed in jobs that require bilingual language skills. It is reasonable to assume that those who commonly use English as a non-work language have greater fluency in English than those who predominantly use French. ${ }^{7}$ Moreover, if the quality of English language skills was uniform among all bilinguals, competition for higher-wage bilingual jobs would tend to reduce the earning differential associated with language use. There is no direct evidence on this but Albouy (2006) notes that the overall bilingual earnings gap for Quebec Francophones has been falling since 1970 (he attributes this fall to a decline in the relative demand for English in Quebec jobs) and this may have compressed

\footnotetext{
${ }^{7}$ Some mixed evidence on these issues is available. Only 226 (2.4 percent) of all bilingual men in our Quebec sample speak English (or English and French) at home; most of these men (77.4 percent) work in jobs that require the frequent or extensive use of English. On the other hand, their earnings are not significantly higher than the earnings
} 
the differential between the earnings of bilinguals who use and those who merely know a second language. ${ }^{8}$

Despite these objections, it is difficult to believe that the difference in the additional returns to language use in Quebec (0.139) and in the ROC (0.016) in column 1, Tables 3 and 2, can be entirely due to more proficient bilingualism in Quebec - as the above arguments would suggest. If we suppose that the 0.016 additional return to language use in the ROC is entirely due to the superior ability/fluency of second language users in the ROC and if, additionally, this is indicative of the situation in Quebec, an 'adjusted' return of $0.123(0.139-0.016)$ would remain for bilingual language users in Quebec. This adjusted return must reflect the overall demand and supply forces in Quebec. Of course, the reward to additional bilingual ability/fluency in Quebec may be higher than the 1.6 percentage points in the ROC, in which case the adjusted return to language use in Quebec may still be high. It is clear, however, that while some uncertainty may remain, the additional return to language use in Quebec, estimated for the first time here, must largely reflect the value of actually using the second language in the Quebec marketplace.

Would it be appropriate to adjust the ROC coefficient of 0.016 by subtracting the Quebec figure of 0.139 , thus producing a negative adjusted effect for the use of the second language in the ROC? We would argue that the answer is no. The limited demand for French in the ROC suggests that the coefficient on second language use may be largely due to the superior ability/fluency of bilingual language users in the ROC. This is almost certainly not true in Quebec, where the demand for English is overwhelming. Thus, adjusting by using the Quebec figure of 0.139 would

of men who use English at work but speak only French at home. The pattern is very similar for Francophone women. ${ }^{8}$ The language use-language knowledge earnings gaps in major urban regions (Montreal, Quebec City, Sherbrooke, and Hull) provide some indirect support for this hypothesis. For example, in Montreal, where 50 percent of all jobs require the use of English, the bilingual earnings gap for workers who frequently use English is 15.8 percent; in Quebec City, where only 24 percent of all jobs are bilingual, the earnings gap is 12.8 percent. Both cities have the same proportion of workers who are bilingual but use only French at work, that is, 26 percent. 
be grossly inappropriate. It is possible, that the market reward for the additional ability/fluency of the bilingual language users in Quebec is higher than in the ROC. This appears to be the last straw on which one can grasp to suggest that the adjusted additional reward to the use of English by Quebec bilinguals is smaller than 0.123 . Doubling or tripling the ROC effect of 0.016 would still leave a very substantial additional effect for the use of English by Quebec bilinguals.

The estimated work-language effects for Francophone women in Quebec are more moderate. Relative to unilinguals, fluency in English increases the earnings of women who use only French at work by 8.1 percent (Equation 3, Table 3); the earnings of those who use English frequently increase by 14.9 percent, while the earnings of women who use English exclusively or extensively increase by 16.2 percent. The use of English at work contributes significant, additional, earnings to bilingual women; the BIL/WORK coefficient is significantly different from zero at the 1 percent level. ${ }^{9}$ However, as in the case of Quebec men, the BIL/ENGLISH coefficient is not significantly different from zero. The adjusted return to language use of bilingual Quebec workers is, at $0.041(0.068-0.027)$, considerably smaller than that for Quebec men.

A comparison of the work-language coefficients estimated from Equations (3) and (4) shows that the inclusion of industry and occupation effects does not alter the coefficients on language to any noteworthy extent. This may be largely the result of several divergent relative employment patterns. First, women who use English at work are moderately over-represented in the high-earnings public sector, but they are severely under-represented in the equally high-

\footnotetext{
${ }^{9}$ The significance test is based on the language coefficients and respective t-values derived from the re-specified earnings equation. The partial results are given below.

BILINGUAL .081 (4.77)

BIL/WORK .068 (3.53)

BIL/ENGLISH -.013 (0.51)
} 
earnings semi-public sector. While 37.5 percent of unilingual Francophone women work in the semi-public sector, only 5.5 and 15.1 percent of women from the BIL/MFFE and BIL/ENGLISH bilingual groups, respectively, are employed in such jobs (Table 2A). This employment pattern suggests that the demand for English language skills may be limited in sectors such as health care and education. Second, while bilingual women who use English at work are twice as likely as unilingual Francophone women to occupy managerial positions, they are only half as likely to work in professional occupations. They are also more likely to work in the relatively lowerpaying white-collar occupations. However, bilingual women who use only French at work exploit their earnings advantage by gravitating disproportionately to jobs in the higher-paying public and semi-public sectors and the managerial/professional occupations.

\section{SUMMARY AND CONCLUDING OBSERVATIONS}

In this study, we estimate the labour market rewards to an investment in English secondlanguage skills by Francophones in Quebec and French second-language skills by Anglophones in the Rest-of-Canada. Unlike earlier studies, which focus on the rewards to language knowledge, we estimate the additional rewards flowing to those who use second language skills, having conditioned on language knowledge. The econometric analysis is based on log earnings equations that utilize individual data from the 2001 Census. Language skills in the ROC are categorized as unilingual English, bilingual/work language English only, bilingual/work language English frequently French, and bilingual/work language mostly or exclusively French; in Quebec, the corresponding categories are unilingual French, bilingual/work language French only, bilingual/work language French frequently English, and bilingual/work language mostly or exclusively English. 
Our analysis shows that in the ROC the earnings of men who are bilingual but work exclusively in English are 3.8 percentage points higher than the earnings of the comparison group of men who are fluent only in English; the earnings of bilingual men who frequently use French at work are 5.4 percentage points higher. However, the difference between these two premiums, which reflects the market value of using French over and above being fluent in it, is not significantly different from zero. The findings for Anglophone women in the ROC are very similar; the main differences are that the earnings premium associated with knowledge of the French language is considerably larger (6.6 percentage points) and the earnings premium of bilingual women who frequently use French at work even larger (9.3 percentage points). As in the case of men, the difference between these premiums, which is a reflection of the value of using a second language, is not significantly different from zero. The number of men and women who use French mostly or exclusively is too small for reliable inference.

Our findings for Quebec are very different. Compared with unilingual Francophones, the earnings of men who are bilingual but work exclusively in French are 7 percentage points higher, and those who frequently use English at work are 20.9 percentage points higher. The difference between these premiums is statistically significant; it shows that the premium associated with the frequent use of English at work is 13.9 percentage points. For women, the general patterns are similar. Relative to unilingual Francophones, the earnings of bilingual women are 8.1 percentage points higher and those of bilingual women who frequently use English at work are 14.9 percentage points higher. The difference between these premiums is statistically significant, indicating a 6.8 percentage point 'return' to the use of English language skills. Francophone men and women who make extensive use of English at work also earn considerably more than 
unilingual Francophones. However, their earnings are not significantly higher than the earnings of bilingual Francophones who use English frequently at work.

Our results suggest that in the ROC the economic effect of French second-language skills is contained essentially in language knowledge rather than language use in market-related activities. A plausible interpretation of these findings, in light of insufficient demand for French in the marketplace, is that these skills may merely signal unobservable labour market characteristics such as ability, cognition, perseverance, and quality of education ('ability' for short), all of which have a bearing on labour productivity. There may be no additional return to language capital. In Quebec as well, a substantial component of the total rewards for English second-language skills is derived from language knowledge; as in the ROC, this component may reflect nothing more than the effect of unobservable labour market characteristics. However, because of the substantial demand for English in the Quebec workplace, a more substantial component of the overall return, especially for Francophone men, is associated with the actual use of language in the workplace. It thus appears that, to realize the full benefits of an investment in English, Francophone men and women must not only know the English language but they must also use it in market-related activities.

This interpretation of our results must, however, be viewed with caution. Only the very able may have the requisite English second-language skills to compete for bilingual jobs. Since information on ability or language fluency is not available, it is not certain that the entire language use-language knowledge earnings differential is attributable to language capital. However, the additional earnings of bilingual users of the second language in the ROC may capture this additional ability/fluency. If bilingual users of the second language in the ROC are equally able/fluent as those in Quebec, then subtracting their differential from that of their Quebec 
counterparts still leaves an adjusted return to the use of English in Quebec which is very substantial. For men, this adjusted effect is 12.3 percentage points while that for women is 4.1 percentage points. These refinements were, due to data limitations, not possible in earlier studies of the value of bilingualism in Canada.

Our findings have implications for the future of bilingual policy in Canada. Economic incentives are critical in the decision to acquire or retain a second language. Fry and Lowell (2001) have argued that the low market value of bilingual language skills in the U.S. labour market has contributed to the rapid shift to monolingualism across generations. In Canada as well, the modest returns to French second-language skills in the ROC have undoubtedly contributed to the slow growth of bilingualism outside Quebec. Despite the active promotion of bilingualism in the ROC, there has been little change over the last three decades in the proportion of the population with bilingual English/French language skills. By contrast, in Quebec, where the economic incentives for acquiring English as a second language are stronger, almost sixty percent of the population is bilingual.

Other influences undoubtedly contribute to this disparity. In a largely English-speaking North America, the cultural incentives in Quebec to acquire English may be considerably stronger than the incentives in the ROC to acquire French. The dominance of English in information technology and the world of science may have similar effects on language incentives. Added to our findings on economic incentives, these considerations suggest that the future of bilingualism in the ROC may be no better than at present. 


\section{REFERENCES}

Allen, Mary. 2004. "Reading Achievements of Students in French Immersion Programs." Educational Quarterly Review 9(4): 25-30.

Albouy,David. 2006. "The Earnings Gap between Francophones and Anglophones: A Canadian Perspective, 1970 to 2000.” Mimeo, University of California, Berkeley, January.

Chiswick, Barry R., and Paul W. Miller. 1988. "Earnings in Canada: The Roles of Immigrant Generations, French Ethnicity, and Language." In Research in Population Economics, ed. T. Paul Schultz, pp. 163-182. Greenwich, Connecticut: JAI Press Inc.

Chorney, Harold. 1998. "Bilingualism in Employee Recruitment and the Role of Symbolic Analysts in Leading Export-Oriented Firms." In New Canadian Perspectives: Economic Approaches to Language and Bilingualism, ed. Albert Breton, pp. 185-222. Ottawa, Canadian Heritage: Department of Public Works and Government Services Canada.

Christofides, Louis N., and Robert Swidinsky. 1998. "Bilingualism and Earnings: A Study Based on 1971, 1981 and 1991 Census Data." In New Canadian Perspectives: Economic Approaches to Language and Bilingualism, ed. Albert Breton, pp. 123-186. Ottawa, Canadian Heritage:

Department of Public Works and Government Services Canada.

CPF (Canadian Parents for French). 2004. The State of French Second Language Education in Canada 2004. Ottawa: Canadian Parents for French.

Currie, J., and D. Thomas. 2001. "Early Test Scores, Socioeconomic Status, School Quality and Future Outcomes." In Research in Labor Economics, Vol. 20: 103-132.

Edwards, John. 2003. “The Importance of Being Bilingual.” In Bilingualism: Beyond Basic Principles, eds. Jean-Marc Dewaele, Alex Housen and Li Wei, pp. 28-42. Clevedon: Multilingual Matters Ltd.

Fry, Richard, and B. Lindsay Lowell. 2001. "The Value of Bilingualism in the U.S. Labor Market." Mimeo: Washington, D.C.: Pew Hispanic Center.

Grenier, Gilles. 1987. "Earnings by Language Group in Quebec in 1980 and Emigration from Quebec between 1978 and 1981." Canadian Journal of Economics XX (November): 774-791.

Husum, R., and R. Bryce. 1991. "A Survey of Graduates from a Saskatchewan French Immersion High School.” Canadian Modern Languages Review 48 (October): 135-143.

Lambert, Wallace E. 1977. "The Effects of Bilingualism on the Individual: Cognitive and Sociocultural Consequences." In Bilingualism Psychological, Social, and Educational Implications, ed. Peter A. Hornby, pp. 15-27. New York: Academic Press, Inc. 
MacFarlane, Alina, and Marjorie Bingham Wesche. 1995. "Immersion Outcomes: Beyond Language Proficiency.” Canadian Modern Languages Review 51 (January): 250-274.

Murmane, Richard J., John B. Willett, and Frank Levy. 1995. "The Growing Importance of Cognitive Skills in Wage Determination." Review of Economics and Statistics, 77 (May): 251266.

Savoie, Ghislain. 1997. "The Comparative Advantages of Bilingualism on the Job Market: Survey of Studies.” In New Canadian Perspectives: Official Languages and the Economy, pp. 65-88. Ottawa, Canadian Heritage: Minister of Public Works and Government Services Canada.

Shapiro, D.M., and M. Stelcner. 1987. "Earnings Disparities among Linguistic Groups in Quebec, 1970-1980." Canadian Public Policy/Analyse de Politiques XIII (March): 97-104.

Shapiro, Daniel M., and Morton Stelcner. 1997. "Language and Earnings in Quebec: Trends over Twenty Years, 1979-1990.” Canadian Public Policy/Analyse de Politiques XXIII (June):1 15-140.

Turnbull, Miles, Sharon Lapkin, and Doug Hart. 2001. 'Grade 3 Immersion Students' Performance in Literacy and Mathematics: Province-Wide Results from Ontario (1998-99)." Canadian Modern Languages Review 58 (September): 9-26.

Vaillancourt, François. 1992. "An Economic Perspective on Language and Public Policy in Canada and the United States." In Immigration, Language, and Ethnicity, Canada and the United States, ed. Barry R. Chiswick, pp. 179-228. Washington, D.C.: The AEI Press.

Vaillancourt, François. 1997. "Economic Costs and Benefits of the Official Languages: Some Observations." In New Canadian Perspectives: Official Languages and the Economy, pp. 103118. Ottawa, Canadian Heritage: Minister of Public Works and Government Services Canada. 


\section{APPENDIX}

All data are taken from the 2001 Census Public Use Microdata File. Variable sources are identified by mnemonic, field, and code (in parenthesis).

lnE: WAGESP-Field 126; Natural log of gross annual wages and salaries.

Region: PROV-Field 1; Atlantic (1-13), Quebec (24), Ontario (35), Prairie (46,47), West (48, 49).

Urban: CMAP-Field 2; Resident in CMA.

Marital Status: MARSTHP-Field 24; Married (2), Divorced/Separated (1, 3, 5), Single (4).

Experience: Age (AGEP-Field 21) - Years of Schooling (TOTSCHP-Field 99) - 6.

Schooling: HLOSP-Field 93; High School (4), Trade/College (5 - 10), Undergraduate Degree (11, $12)$, Graduate Degree $(13,14)$.

Language: OLNP-Field 67, MTNP-Field 68, WLNAP-Field 88, and WLNBP-Field 89; In ROC, UNIL/ENGLISH (Mother tongue English, Official language English only, work language English only); BIL/MEFE (Mother tongue English, Official languages English and French, work language English only); BIL/MEFF (Mother tongue English, Official languages English and French, work languages mostly English frequently French); BIL/FRENCH (Mother tongue English, Official languages English and French, work language French only, French mostly English frequently, or English and French). In Quebec, UNIL/FRENCH (Mother tongue French, Official Language French only, work language French only); BIL/MFFF (Mother tongue French, Official languages French and English, work language French only); BIL/MFFE (Mother tongue French, Official languages French and English, work languages mostly French frequently English);

BIL/ENGLISH (Mother tongue French, Official languages French and English, work languages English only, English mostly French frequently, or French and English).

Occupation: NOCSO1P-Field 114; Occup1 (1, 2), Occup2 (3-5), Occup3 (6-8), Occup4 (9-11), Occup5 (12-17), Occup6 (18-22), Occup7 (23-25); Manager (Occup1), Professional (Occup3-4), White Collar (Occup2, 5), Blue Collar (Occup6, 7).

Industry: IND80P-Field 115; Ind1 (1-6), Ind2 (7, 8), Ind3 (9, 10), Ind4 (11, 12), Ind5 (13, 14), Ind6 (15, 16); Public (Ind4), Semi-Public (Ind5), Private (Ind1, 2, 3, 6). 
TABLE 1a

Sample Size and Average Annual Earnings for the Rest of Canada

\begin{tabular}{|c|c|c|c|c|c|}
\hline & $\begin{array}{r}\text { Sample } \\
\text { Size }\end{array}$ & $\begin{array}{l}\text { Percent of } \\
\text { Total Sample }\end{array}$ & $\begin{array}{r}\text { Percent of } \\
\text { Bilingual }\end{array}$ & $\begin{array}{r}\text { Annual } \\
\text { Earnings } \\
\$\end{array}$ & $\begin{array}{r}\text { Percent } \\
\text { Differential }\end{array}$ \\
\hline & \multicolumn{5}{|c|}{ Men } \\
\hline Total Sample & 44,557 & 100.0 & - & 52,739 & - \\
\hline Unilingual & 41,580 & 93.3 & - & 52,223 & - \\
\hline Bilingual & 2,977 & 6.7 & 100.0 & 59,922 & 14.7 \\
\hline BIL/MEFE & 2,137 & 4.8 & 71.8 & 60,178 & 15.2 \\
\hline BIL/MEFF & 737 & 1.6 & 24.7 & 60,914 & 16.6 \\
\hline \multirow[t]{2}{*}{ BIL/FRENCH } & 103 & 0.2 & 3.5 & 47,49 & -9.1 \\
\hline & \multicolumn{5}{|c|}{ Women } \\
\hline Total Sample & 33,944 & 100.0 & - & 37,154 & - \\
\hline Unilingual & 30,990 & 91.3 & - & 36,567 & - \\
\hline Bilingual & 2,954 & 8.7 & 100.0 & 43,319 & 18.5 \\
\hline BIL/MEFE & 2,030 & 6.0 & 68.7 & 43,269 & 18.3 \\
\hline BIL/MEFF & 718 & 2.1 & 24.3 & 44,971 & 23.0 \\
\hline BIL/FRENCH & 206 & 0.6 & 7.0 & 38,063 & 4.1 \\
\hline
\end{tabular}

Table 1b

Sample Size and Average Annual Earnings for Quebec

\begin{tabular}{lrrrrr}
\hline & \multicolumn{5}{c}{ Men } \\
\cline { 2 - 6 } Total Sample & 15,836 & 100.0 & - & 46,071 & - \\
Unilingual & 6,454 & 40.8 & - & 39,559 & - \\
Bilingual & 9,382 & 59.2 & 100.0 & 50,559 & 27.9 \\
BIL/MFFF & 3,837 & 24.2 & 40.9 & 46,036 & 16.4 \\
BIL/MFFE & 4,095 & 25.8 & 43.6 & 53,641 & 35.6 \\
BIL/ENGLISH & 1,450 & 9.2 & 15.5 & 54,256 & 37.1 \\
& & & & & \\
Total Sample & 12,448 & 100.0 & - & 34,352 & - \\
Unilingual & 5,917 & 47.5 & - & 30,804 & - \\
Bilingual & 6,531 & 52.5 & 100.0 & 37,563 & 21.9 \\
BIL/MFFF & 2,673 & 21.5 & 40.9 & 37,43 & 21.5 \\
BIL/MFFE & 2,823 & 22.7 & 43.2 & 37,58 & 22.0 \\
BIL/ENGLISH & 1,035 & 8.3 & 15.9 & 37,859 & 22.9 \\
\hline
\end{tabular}


TABLE 2

Ln Earnings Regression Results for Men and Women in ROC (|t|-statistics in parentheses)

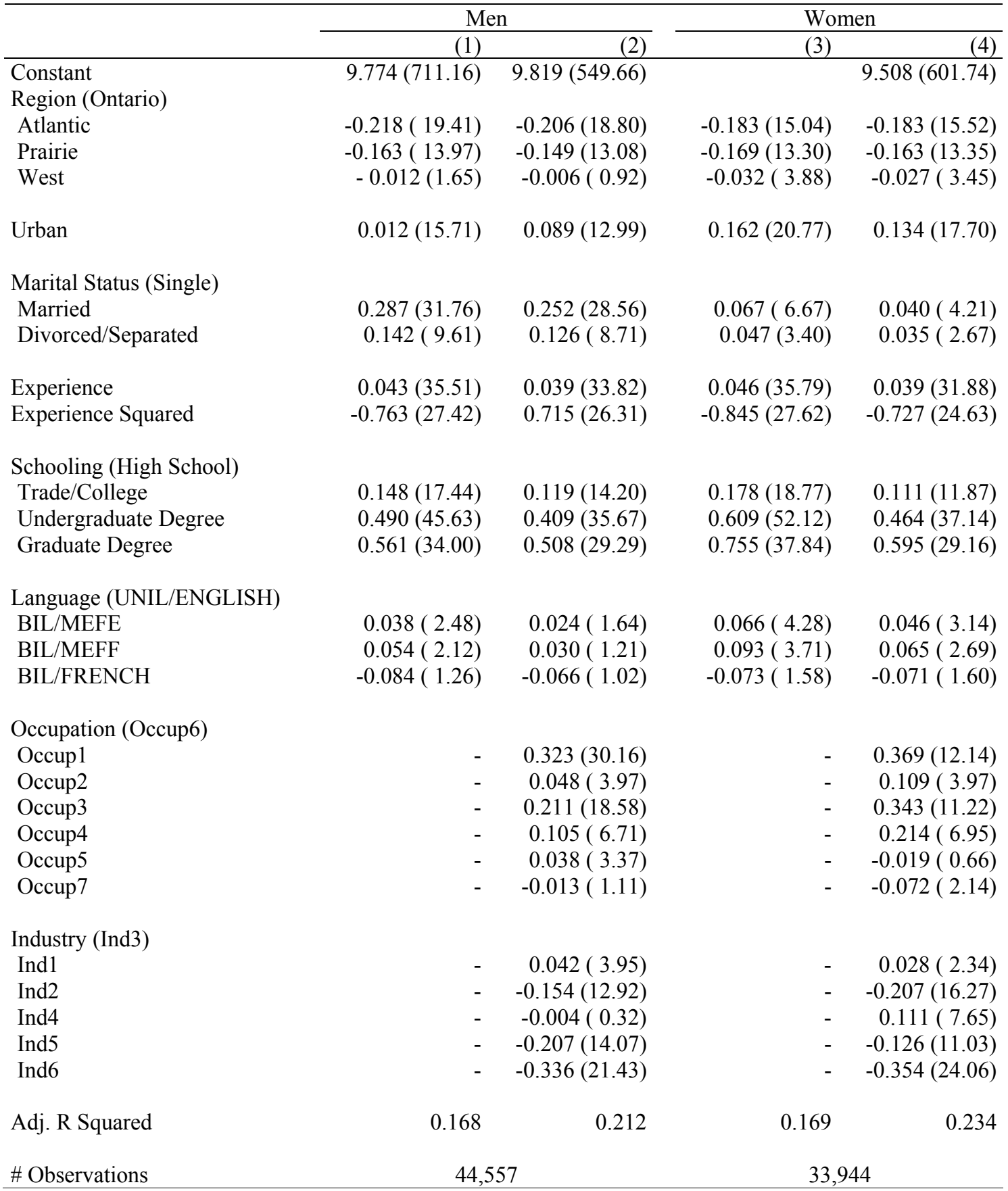


TABLE 3

Ln Earnings Regression Results for Men and Women in Quebec ( $|\mathrm{t}|$-statistics in parentheses)

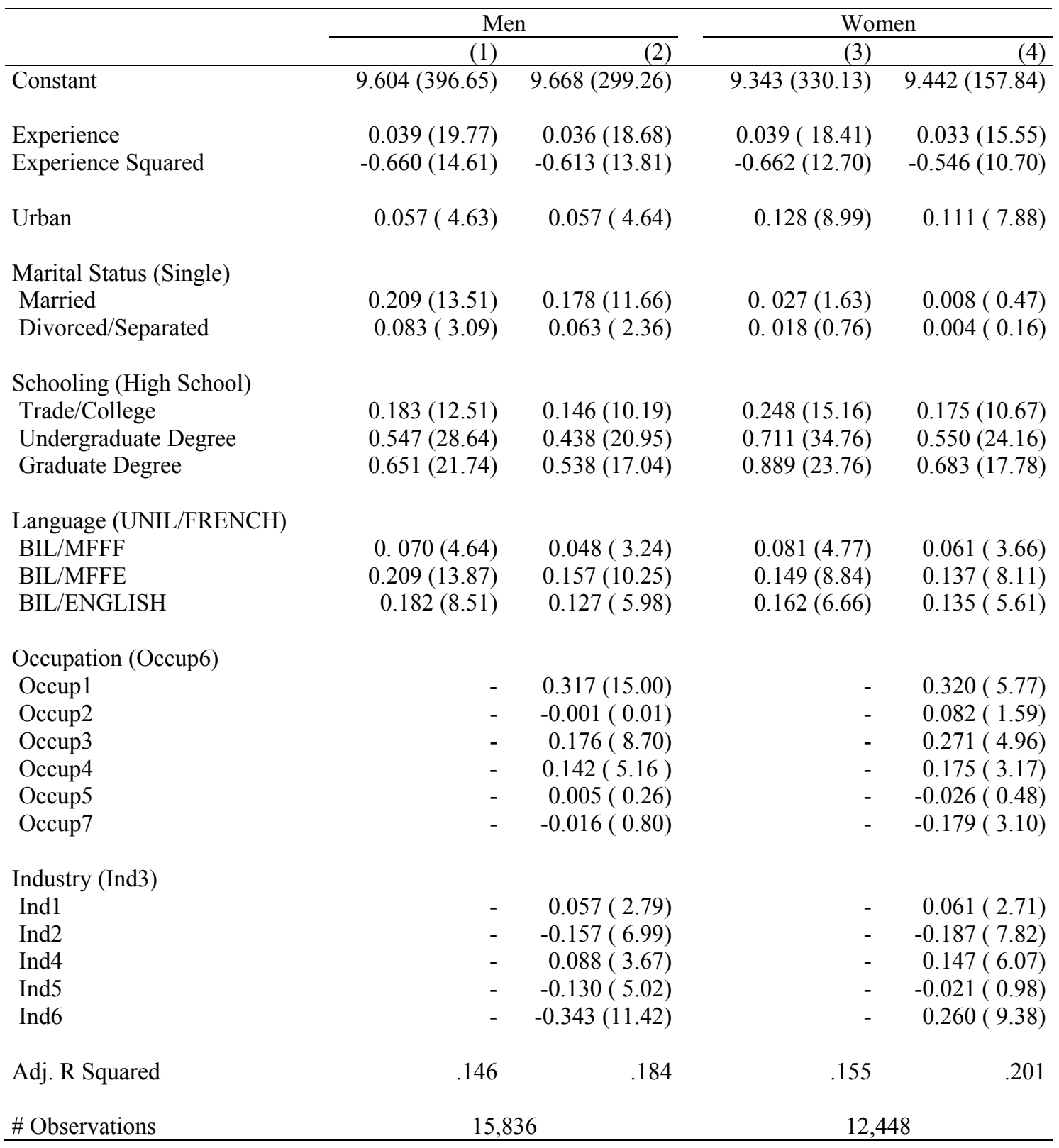


APPENDIX TABLE 1A

Employment Distribution by Sector, Occupation and Work-Language, ROC

\begin{tabular}{|c|c|c|c|c|c|}
\hline & $\begin{array}{r}\text { Average } \\
\text { Earnings } \\
\$\end{array}$ & $\begin{array}{r}\text { UNIL/ } \\
\text { ENGLISH } \\
\%\end{array}$ & $\begin{array}{r}\mathrm{BIL} / \\
\mathrm{MEFE} \\
\%\end{array}$ & $\begin{array}{r}\mathrm{BIL} / \\
\mathrm{MEFF} \\
\%\end{array}$ & $\begin{array}{r}\text { BIL/ } \\
\text { FRENCH } \\
\%\end{array}$ \\
\hline & \multicolumn{5}{|c|}{ Men } \\
\hline Sector & & & & & \\
\hline Public & 54,965 & 8.8 & 12.8 & 33.2 & 14.6 \\
\hline Semi Public & 51,908 & 8.6 & 13.5 & 12.8 & 31.1 \\
\hline Private & 52,574 & 82.6 & 73.7 & 54.0 & 54.3 \\
\hline \multicolumn{6}{|l|}{ Occupation } \\
\hline Manager & 71,190 & 17.1 & 22.7 & 29.3 & 16.5 \\
\hline Professional & 57,630 & 21.2 & 34.7 & 30.6 & 42.6 \\
\hline White Collar & 46,667 & 26.3 & 25.5 & 31.5 & 19.3 \\
\hline Blue Collar & 44,731 & 35.3 & 16.8 & 8.4 & 21.3 \\
\hline & \multicolumn{5}{|c|}{ Women } \\
\hline Sector & & & & & \\
\hline Public & 44,372 & 8.0 & 9.7 & 22.6 & 8.3 \\
\hline Semi-Public & 39,827 & 31.8 & 33.7 & 34.0 & 59.7 \\
\hline Private & 34,689 & 60.2 & 56.6 & 43.4 & 32.0 \\
\hline \multicolumn{6}{|l|}{ Occupation } \\
\hline Manager & 48,121 & 11.9 & 16.8 & 16.7 & 5.3 \\
\hline Professional & 43,274 & 29.7 & 40.8 & 38.9 & 61.5 \\
\hline White Collar & 31,577 & 53.2 & 39.1 & 42.8 & 32.5 \\
\hline Blue Collar & 30,214 & 4.9 & 3.1 & 1.3 & 0.4 \\
\hline
\end{tabular}


APPENDIX TABLE 1B

Employment Distribution by Sector, Occupation and Work-Language, Quebec

\begin{tabular}{lrrrrr}
\hline & $\begin{array}{r}\text { Average } \\
\text { Earnings } \\
\$\end{array}$ & $\begin{array}{r}\text { UNIL/ } \\
\text { FRENCH } \\
\%\end{array}$ & $\begin{array}{r}\text { BIL/ } \\
\text { MFF } \\
\%\end{array}$ & $\begin{array}{r}\text { BIL/ } \\
\text { MFFE } \\
\%\end{array}$ & $\begin{array}{r}\text { BIL/ } \\
\text { ENGLISH } \\
\%\end{array}$ \\
\cline { 2 - 6 } Sector & \multicolumn{3}{c}{ Men } \\
Public & 53,566 & 8.6 & 13.1 & 11.8 & 11.2 \\
Semi-Public & 47,229 & 11.5 & 17.0 & 5.5 & 4.8 \\
Private & 44,947 & 79.9 & 69.9 & 82.7 & 83.9 \\
& & & & & \\
Occupation & & & & & \\
Manager & 65,997 & 7.1 & 12.6 & 22.5 & 18.7 \\
Professional & 51,314 & 17.4 & 31.2 & 27.3 & 27.7 \\
White Collar & 40,534 & 24.5 & 25.1 & 31.4 & 31.2 \\
Blue Collar & 39,215 & 51.0 & 31.0 & 18.9 & 22.3 \\
& & & & & \\
Sector & & & Women & & \\
Public & & & & & \\
Semi-Public & 41,656 & 9.5 & 12.5 & 11.8 & 16.4 \\
Private & 38,081 & 37.5 & 39.5 & 5.5 & 15.1 \\
Occupation & 30,867 & 53.0 & 48.0 & 82.7 & 68.5 \\
Manager & & & & & \\
Professional & 45,441 & 5.9 & 8.7 & 12.8 & 11.7 \\
White Collar & 40,851 & 32.7 & 43.2 & 24.6 & 22.8 \\
Blue Collar & 29,676 & 52.4 & 43.1 & 60.2 & 62.0 \\
\hline
\end{tabular}

